\title{
Ginsenoside Rb1 Attenuates Agonist- Induced Contractile Response via Inhibition of Store-Operated Calcium Entry in Pulmonary Arteries of Normal and Pulmonary Hypertensive Rats
}

\author{
Rui-Xing Wang ${ }^{a, b}$ Rui-Lan He $e^{a, b}$ Hai-Xia Jiao a,b Mao Daia,b Yun-Ping Mu ${ }^{a, b}$ \\ Ying Hu $\mathrm{Hu}^{\mathrm{a}, \mathrm{b}}$ Zhi-Juan Wu $\mathrm{u}^{\mathrm{a}, \mathrm{b}}$ James S.K. Sham ${ }^{\mathrm{a}, \mathrm{b}, \mathrm{c}}$ Mo-Jun Lin ${ }^{\mathrm{a}, \mathrm{b}}$ \\ aDepartment of Physiology and Pathophysiology, School of Basic Medical Sciences, Fujian Medical \\ University, Fuzhou, bLaboratory of Cardiovascular Sciences, School of Basic Medical Sciences, Fujian \\ Medical University, Fuzhou, People's Republic of China; 'Division of Pulmonary and Critical Care \\ Medicine, Johns Hopkins University School of Medicine, Baltimore, Maryland, USA
}

\section{Key Words}

Ginsenoside Rb1 - Store-operated calcium entry - Pulmonary hypertension - Monocrotaline - Chronic hypoxia

\footnotetext{
Abstract

Background: Pulmonary hypertension $(\mathrm{PH})$ is characterized by sustained vasoconstriction, enhanced vasoreactivity and vascular remodeling, which leads to right heart failure and death. Despite several treatments are available, many forms of PH are still incurable. Ginsenoside Rb1, a principle active ingredient of Panax ginseng, exhibits multiple pharmacological effects on cardiovascular system, and suppresses monocrotaline (MCT)-induced right heart hypertrophy. However, its effect on the pulmonary vascular functions related to PH is unknown. Methods: We examined the vasorelaxing effects of ginsenoside Rb1 on endothelin-1 (ET-1) induced contraction of pulmonary arteries (PAs) and store-operated $\mathrm{Ca}^{2+}$ entry (SOCE) in pulmonary arterial smooth muscle cells (PASMCs) from chronic hypoxia $(\mathrm{CH})$ and $\mathrm{MCT}$-induced PH. Results: Ginsenoside Rb1 elicited concentration-dependent relaxation of ET-1-induced PA contraction. The vasorelaxing effect was unaffected by nifedipine, but abolished by the SOCE blocker $\mathrm{Gd}^{3+}$. Ginsenoside Rb1 suppressed cyclopiazonic acid (CPA)-induced PA contraction, and CPAactivated cation entry and $\mathrm{Ca}^{2+}$ transient in PASMCs. ET-1 and CPA-induced contraction, and CPA-activated cation entry and $\mathrm{Ca}^{2+}$ transients were enhanced in PA and PASMCs of $\mathrm{CH}$ and MCT-treated rats; the enhanced responses were abolished by ginsenoside Rb1. Conclusion: Ginsenoside Rb1 attenuates ET-1-induced contractile response via inhibition of SOCE, and it can effectively antagonize the enhanced pulmonary vasoreactivity in $\mathrm{PH}$.

Copyright @ 2015 S. Karger AG, Basel

R.-X. Wang; R.-L. He and H.-X. Jiao have equal contribution to this publication.

Mo-Jun Lin, M.D. Ph.D.

James S.K. Sham, Ph.D.

KARGER 125

Dept Physiol and Pathophysiol, Fujian Medical University,1 Xueyuan Road, Shangjie Zhen, Minhou County, Fuzhou, Fujian Province 350108, (P.R. China) and Div of Pulmonary and Critical Care Medicine, Johns Hopkins University School of Medidine,5501 Hopkins Bayview Circle, Baltimore, MD 21204 (USA) E-Mail mjlin@mail.fjmu.edu.cn, E-Mail jsks@jhmi.edu
} 


\section{Cellular Physiology Cell Physiol Biochem 2015;35:1467-1481 \begin{tabular}{l|l} 
and Biochemistry Published online: March 12, 2015 & $\begin{array}{l}\text { DO 2015 S. Karger AG, Basel } \\
\text { www.karger.com/cpb }\end{array}$ \\
\hline
\end{tabular} \\ Wang et al.: Ginsenoside Rb1 Attenuates Store-Operated Calcium Entry}

\section{Introduction}

Pulmonary hypertension (PH) is a pathophysiological condition associated with a board spectrum of diseases of different pathological features and etiological mechanisms [1]. It is characterized by progressive pulmonary vascular remodeling, sustained vasoconstriction and enhanced vasoreactivity, resulting in elevated pulmonary vascular resistance and eventually leading to right heart failure and even death [2]. The pathogenesis of $\mathrm{PH}$ is complex involving many different mechanisms and signaling pathways. Accumulating evidence suggest that there are major intrinsic changes in ionic balance and $\mathrm{Ca}^{2+}$ homeostasis in pulmonary arterial smooth muscle cells (PASMCs) in many forms of $\mathrm{PH}$, and the aberrant alterations in $\mathrm{Ca}^{2+}$ signaling in PASMCs play pivotal roles in the augmented pulmonary vasoconstriction and vascular remodeling in $\mathrm{PH}$ [3]. However, despite several effective treatments have become available in recent years, many forms of $\mathrm{PH}$ are still incurable and the mortality rates are very high $[4,5]$. Hence, research on novel therapies that can improve the modality of treatment is urgently needed.

Ginseng, the root of Panax ginseng, is a well-known oriental traditional medicine. It has been used widely as a tonic for various disorders in China, Korea and Japan for over two thousand years and is now a popular herbal remedy worldwide. Ginsenosides, the bioactive ingredients of ginseng, have been proven to provide therapeutic effects affecting the cardiovascular, endocrine, immune, and central nervous systems [6-9]. Ginsenosides are generally classified into two categories, namely the panaxadiols and the panaxatriols. Ginsenoside $\mathrm{Rb} 1$ is one of most abundant panaxadiols that possesses many beneficial effects on the cardiovascular system. Previous studies have demonstrated that ginsenoside Rb1 promotes endothelial nitric oxide production [10], suppresses intimal hyperplasia after vascular injury [11-13], protects against endothelial dysfunction [14] and inhibits inflammatory responses in vascular smooth muscle cells [15]. It also suppresses apoptosis and oxidative injury of cardiomyocytes [16-20]; and protect against ischemic-reperfusion injury [21, 22], dilated cardiomyopathy [23] and cardiac hypertrophy [24]. A previous study showed that ginsenoside $\mathrm{Rb} 1$ can suppress and reverse the development of right heart hypertrophy in monocrotaline (MCT)-treated rats, and the finding was explained by an inhibitory effect of ginsengoside $\mathrm{Rb} 1$ on the calcineurin-NFAT signaling pathway in cardiomyocytes [24]. However, the primary cause of MCT-induced right heart hypertrophy is pulmonary arterial hypertension (PAH) triggered by the toxic effect of the metabolite monocrotaline pyrrole on the pulmonary endothelial cells [25]. Hence, this raised the interesting possibility that ginsenoside $\mathrm{Rb} 1$ may exert its cardiac protective effect on MCTtreated rats through the suppression of PAH.

Alteration in pulmonary vasoreactivity is one of the salient features of $\mathrm{PH}$ [26]. Previous studies have shown that vasoreactivity to agonists such as ET-1, 5-HT and Ang II are enhanced in PAs of different PH rat and mouse models [27-33]. We have recently shown that the enhanced vasoreactivity to ET-1 in PAs of MCT-treated rats is related to the upregulation of store-operated $\mathrm{Ca}^{2+}$ entry (SOCE). In the present study, we sought to investigate the possible therapeutic actions of ginsenoside $\mathrm{Rb} 1$ on $\mathrm{PH}$ by examining its effects on the contractile responses and vasoreactivity to ET-1 in PAs of chronic hypoxia $(\mathrm{CH})$ and MCT-induced PH rats, and by interrogating the underlying mechanisms.

\section{Materials and Methods}

\section{Animals and PH models}

Experiments were performed on male Sprague-Dawley rats (200-250 g) supplied by the animal center of the Fujian Medical University (Fuzhou, China). All procedures were approved by the Animal Care and Use Committee of Fujian Medical University.CH-induced PH was produced by established method [34, 35]. Male Sprague-Dawley rats were placed in a hypoxic chamber and exposed to either normoxia or normobaric hypoxia $10 \% \mathrm{O}_{2}$ for 3 weeks. MCT-induced PH was generated by a single intraperitoneal injection of MCT (50 


\section{Cellular Physiology Cell Physiol Biochem 2015;35:1467-1481

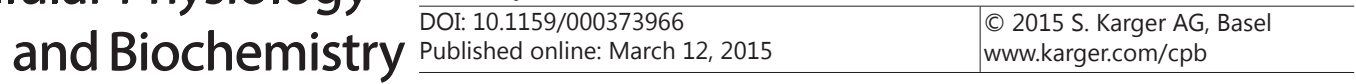 \\ Wang et al.: Ginsenoside Rb1 Attenuates Store-Operated Calcium Entry}

$\mathrm{mg} / \mathrm{kg}$ ) [36]. Twenty-one days after MCT injection or $\mathrm{CH}$ exposure, rats were anesthetized with urethane $(1 \mathrm{~g} / \mathrm{kg})$. Right ventricle systolic pressure (RVSP) was measured by accessing the right ventricle through the jugular vein, using a polyethylene catheter connected to a pressure transducer (YPJ01; Chengyi, China). Pressure signals were displayed continuously on an RM6240 polygraph (Chengyi, China). At the end of hemodynamic measurement, the rat was sacrificed with an overdose of urethane. The heart was removed, and right ventricular mass index (RVMI) was calculated as the ratio of wet weight of the right ventricle to the left ventricular wall plus septum $[\mathrm{RV} /(\mathrm{LV}+\mathrm{S})]$.

\section{Isometric contraction of pulmonary artery ring}

Rats were injected with heparin and anesthetized with urethane $(1 \mathrm{~g} / \mathrm{kg})$. They were exsanguinated, and the lungs were removed and transferred to a petri dish filled with cold $\left(4^{\circ} \mathrm{C}\right)$ oxygenated modified Krebs solution containing (in mM) $118 \mathrm{NaCl}, 4.7 \mathrm{KCl}, 1.2 \mathrm{MgSO}_{4}, 1.18 \mathrm{KH}_{2} \mathrm{PO}_{4}, 25 \mathrm{NaHCO}_{3}, 10$ glucose, and $2 \mathrm{CaCl}_{2}$. Under a dissecting microscope, the third- and fourth-generation pulmonary arteries (PAs) ( $\sim 300$ to 800 $\mu \mathrm{m})$ were isolated and cleaned free of connective tissue. Then they were cut into 4-mm-length rings. The endothelium was removed by gently rubbing the lumen with a small wooden stick, and the arterial rings were suspended between two stainless steel stirrups in organ chambers filled with modified Krebs solution for isometric tension recording. The solution was gassed with $95 \% \mathrm{O}_{2} / 5 \% \mathrm{CO}_{2}$ to maintain a $\mathrm{pH}$ of 7.4 and a temperature at $37^{\circ} \mathrm{C}$. Isometric contraction was measured using a force transducer (JZJ01H; Chengyi, China) connected to an RM6240 polygraph. Resting tension was adjusted to 0.8-1.0 g. Arteries were exposed to 60 $\mathrm{mM} \mathrm{KCl}$ to established maximum contraction and to phenylephrine $\left(3 \times 10^{-7} \mathrm{M}\right)$ followed by acetylcholine $\left(10^{-6} \mathrm{M}\right)$ to verify complete disruption of endothelium. Because $\mathrm{Gd}^{3+}$ is known to be insoluble in phosphate and bicarbonate-containing buffer [15], a bath solution containing (in mM) $118.3 \mathrm{NaCl}, 4.7 \mathrm{KCl}, 2 \mathrm{CaCl}_{2}, 1.2$ $\mathrm{MgCl}_{2}, 10$ HEPES, 11.1 glucose, and $\mathrm{pH}$ adjusted to 7.4 with $\mathrm{NaOH}$, was used in the $\mathrm{Gd}^{3+}$ experiment.

Culture of pulmonary arterial smooth muscle cells

Pulmonary arterial smooth muscle cells (PASMCs) were enzymatically isolated and transiently cultured as previously described [34, 36]. Briefly, lungs were removed and transferred to a petri dish filled with cold HEPES-buffered salt solution (HBSS) containing (in mM) $130 \mathrm{NaCl}, 5 \mathrm{KCl}, 1.2 \mathrm{MgCl}_{2}, 1.5 \mathrm{CaCl}_{2}$, 10 HEPES, and 10 glucose, pH 7.4 (adjusted with $\mathrm{NaOH}$ ). The third- and fourth-generation PAs ( 300 to $800 \mu \mathrm{m})$ were isolated and cleaned free of connective tissue. The endothelium was removed by gently rubbing the luminal surface with a cotton swab. Arteries were then allowed to recover for $30 \mathrm{~min}$ in cold HBSS, followed by $20 \mathrm{~min}$ in reduced-Ca ${ }^{2+}(20 \mu \mathrm{M})$ HBSS at room temperature. The tissue was digested at $37^{\circ} \mathrm{C}$ for $20 \mathrm{~min}$ in $20 \mu \mathrm{M} \mathrm{Ca}^{2+} \mathrm{HBSS}$ containing collagenase (type I, $1750 \mathrm{U} / \mathrm{ml}$ ), papain $(9.5 \mathrm{U} / \mathrm{ml}$ ), bovine serum albumin $(2 \mathrm{mg} / \mathrm{ml})$, and dithiothreitol $(1 \mathrm{mM})$, then removed and washed with $\mathrm{Ca}^{2+}$-free HBSS to stop digestion. PASMCs were dispersed gently by trituration with a small-bore pipette in $\mathrm{Ca}^{2+}$-free HBSS at room temperature. The cell suspension was placed on $25 \mathrm{~mm}$ glass cover slips and transiently $(18-24 \mathrm{~h})$ cultured in Ham's F-12 medium (with L-glutamine) supplemented with $0.5 \%$ fetal calf serum, $100 \mathrm{U} / \mathrm{ml}$ of streptomycin, and $0.1 \mathrm{mg} / \mathrm{ml}$ of penicillin.

Measurement of $\left[\mathrm{Ca}^{2+}\right]_{i}$ and $\mathrm{Mn}^{2+}$ quenching of Fura-2

$\left[\mathrm{Ca}^{2+}\right]_{\mathrm{i}}$ were monitored using the membrane-permeable $\mathrm{Ca}^{2+}$-sensitive fluorescent dye fluo-3 AM as previously described $[34,36]$. PASMCs were loaded with 5-10 $\mu \mathrm{M}$ fluo-3 AM for 30-45 min at room temperature $\left(\sim 22^{\circ} \mathrm{C}\right)$ in normal Tyrode solution containing (in mM) $137 \mathrm{NaCl}, 5.4 \mathrm{KCl}, 2 \mathrm{CaCl} 2,1 \mathrm{MgCl} 2$, 10 HEPES, and 10 glucose, $\mathrm{pH} 7.4$ (adjusted with $\mathrm{NaOH}$ ). Cells were then washed thoroughly with Tyrode solution to remove extracellular fluo-3 AM and rested for 15-30 min to allow for complete deesterification of cytosolic dye. fluo-3 AM was excited at $488 \mathrm{~nm}$, and emission light at $>515 \mathrm{~nm}$ was detected using a Nikon TE2000U microscope equipped with epifluorescence attachments and a microfluometer (PTI, USA). Protocols were executed, and data were collected online with an analog-to-digital interface (FeliX32; PTI). $\left[\mathrm{Ca}^{2+}\right]_{\mathrm{i}}$ was calibrated using the equation $\left[\mathrm{Ca}^{2+}\right]_{\mathrm{i}}=K_{\mathrm{d}}\left(\mathrm{F}-\mathrm{F}_{\mathrm{bg}}\right) /\left(\mathrm{F}_{\text {max }}-\mathrm{F}\right)$, where $\mathrm{F}_{\mathrm{bg}}$ is background fluorescence and $\mathrm{F}_{\max }$ is the maximum fluorescence determined in situ in cells superfused with $10 \mu \mathrm{M}$ 4-bromo-A-23187 and $10 \mathrm{mM} \mathrm{Ca}^{2+}$, and $\mathrm{Kd}$ of fluo-3 AM is $1.1 \mu \mathrm{M}$. Cation entry through SOCC was quantified by quenching of fura-2 with $\mathrm{Mn}^{2+}$. PASMCs were loaded with fura- $2 \mathrm{AM}$ as described above. Fura- 2 was excited at the $\mathrm{Ca}^{2+}-$ insensitive isobestic point of $360 \mathrm{~nm}$, and emission light was recorded at $510 \mathrm{~nm}$ (PTI, USA). PASMCs were then bathed in a $\mathrm{Ca}^{2+}$ free (with $0.1 \mathrm{mM}$ EGTA) Tyrode solution containing $3 \mu \mathrm{M}$ nifedipine. After a stable 


\section{Cellular Physiology Cell Physiol Biochem 2015;35:1467-1481 \begin{tabular}{l|l} 
and Biochemistry Published online: March 12, 2015 & $\begin{array}{l}\text { DO 2015 S. Karger AG, Basel } \\
\text { www.karger.com/cpb }\end{array}$ \\
\hline
\end{tabular} \\ Wang et al.: Ginsenoside Rb1 Attenuates Store-Operated Calcium Entry}

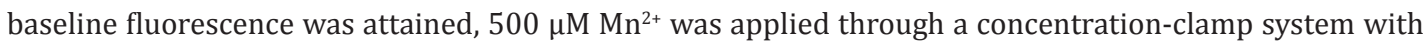
the multi-barrel pipette positioned $<50 \mu \mathrm{m}$ from PASMCs. The rates of quenching of fura- 2 fluorescence and $\left[\mathrm{Ca}^{2+}\right]_{\mathrm{i}}$ in PASMCs with or without drugs treatments were determined and compared.

\section{Solutions and Drugs}

Ginsenoside Rb1 (purity $\geq 98 \%$ ) was purchased from Chengdu Gelei Xiya Chemical Technology Co. Ltd. (Chengdu, China). Fluo-3 AM and fura-2 AM were purchased from Life Technologies (U.S.A.). All the other drugs were purchased from Sigma Chemicals Co. (U.S.A.). Ginsenoside Rb1, nifedipine and CPA were dissolved in dimethyl sulfoxide (DMSO). Fluo-3 AM and fura-2 AM were dissolved in DMSO with 20\% pluronic acid. The final amount of DMSO in the bath solution was less than $0.1 \%$. MCT was dissolved in $1 \mathrm{M}$ $\mathrm{HCl}$, neutralized to $\mathrm{pH} 7.4$ with $1 \mathrm{M} \mathrm{NaOH}$, and diluted with saline. All the other reagents were dissolved in distilled water. All stock solutions were stored at $-20^{\circ} \mathrm{C}$.

\section{Statistical Analysis}

Data are expressed as mean \pm S.E.M., and $n$ indicates the number of animals, PA rings, or cell samples used. Curve fitting was performed using the SigmaPlot 11.0 software. Statistical significance was assessed using unpaired or paired Student's t-tests and ANOVA wherever appropriate. Differences were considered significant at $\mathrm{P}<0.05$.

\section{Results}

Vasorelaxing effects of ginsenoside Rb1 in PAs

The vascular effect of ginsenoside Rb1 was examined in endothelium denuded PA rings. Ginsenoside $\mathrm{Rb} 1$ at concentration of 0.1 to $300 \mu \mathrm{M}$ had negligible effect on the resting tension of PA. In PA precontracted with $60 \mathrm{mM} \mathrm{KCl}$, ginsenoside $\mathrm{Rb} 1$ caused slight concentrationdependent relaxation (Fig. $1 \mathrm{~A}$ and $\mathrm{D}$ ) with the maximal relaxation $\left(\mathrm{E}_{\max }\right)$ of $-19.7 \pm 1.4 \%$ and an IC $\mathrm{IC}_{50}$ of $5.4 \pm 0.2 \mu \mathrm{M}$, suggesting that it has a very small inhibitory effect on the voltage-gated $\mathrm{Ca}^{2+}$ channels. The KCl-induced contraction was very stable in the absence of ginsenoside $\mathrm{Rb} 1$ throughout the course of experiment (n=9) (Fig. $1 \mathrm{E}$ ). Ginsenoside Rb1 caused dramatic relaxation in PA precontracted with $10 \mathrm{nM}$ endothelin-1 (ET-1) in the absence or presence of nifedipine $(3 \mu \mathrm{M})$ (Fig. $1 \mathrm{~B}$ and $\mathrm{C}$ ). The $\mathrm{E}_{\max }$ were $-48.3 \pm 1.8$ and $-44.2 \pm 1.2 \%$; and the $\mathrm{IC}_{50} \mathrm{~s}$ were $4.3 \pm 0.2$ and $3.1 \pm 0.2 \mu \mathrm{M}$ in PA with and without nifedipine treatment, respectively. There was no significant difference between the nifedipine-treated and untreated PAs. The ET-1 induced contraction was relatively stable in the absence of ginsenoside Rb1, with only about $10 \%$ reduction throughout the course of experiment ( $\mathrm{n}=9$ ) (Fig. 1F). These results suggest that ginsenoside Rb1 relaxes ET-1 induced PA contraction mainly through a mechanism independent of voltage-gated $\mathrm{Ca}^{2+}$ entry.

Effect of ginsenoside Rb1 on ET-1-induced contraction in PAs of PH rats

Previous study showed that ET- 1 induced PA constraction is enhanced in PH $[26,36$, 37]. We compared the vasorelaxing effect of ginsenoside Rb1 on ET- 1 induced contraction of PAs isolated from control, $\mathrm{CH}$ - and MCT-induced PH rats. In the presence of $3 \mu \mathrm{M}$ nifedipine, ET-1 (10 nM) elicited significantly greater contraction in PAs of CH- and MCT-treated rats compared to control rats (control: $105.6 \pm 3.3 \% 60 \mathrm{mM} \mathrm{KCl}$-induced contraction, $\mathrm{n}=12$; $\mathrm{CH}$ : $126.7 \pm 4.2 \%, n=12, p<0.05$; MCT: $129.2 \pm 5.3 \%, n=13, p<0.05$ )(Fig. 2). Preincubation with 10 $\mu \mathrm{M}$ ginsenoside $\mathrm{Rb} 1$ for 8 minutes significantly reduced the ET- 1 induced response in PAs of all three groups (control: $84.2 \pm 2.9 \%, \mathrm{n}=12$, $\mathrm{p}<0.01$; $\mathrm{CH}$ : $58.4 \pm 2.6 \%, \mathrm{n}=12, \mathrm{p}<0.01$; and MCT: $66.6 \pm 3.9 \%, n=13, p<0.01$ )(Fig. 2D). The percent inhibition of ET-1 induced contraction by ginsenoside $\mathrm{Rb} 1$ was significantly higher in PAs of $\mathrm{CH}-$ and MCT-treated rats (control: $-20.3 \pm 2.7 \%, \mathrm{n}=12$; CH: $-53.9 \pm 2.1 \%, \mathrm{n}=12$, $\mathrm{p}<0.01$; and MCT: $-48.5 \pm 3.0 \%, \mathrm{n}=13, \mathrm{p}<0.01$ )(Fig. $2 \mathrm{E})$.

We have previously shown that ET-1 induced pulmonary vasoconstriction is in part mediated through store-operated $\mathrm{Ca}^{2+}$ entry (SOCE), which is upregulated in PAs of $\mathrm{CH}$ and 
Fig. 1. Vascular effect of ginsenoside $\mathrm{Rb} 1$ on pulmonary artery (PA) rings in control rats. (A-C) Typical traces of ginsenoside Rb1-induced concentration-dependent relaxation in PA rings precontracted with $60 \mathrm{mM} \mathrm{KCl}$, $10 \mathrm{nM}$ ET-1 and $10 \mathrm{nM}$ ET-1 pretreated with $3 \mu \mathrm{M}$ nifedipine (Nif). (D) The average percent relaxation elicited by ginsenoside $\mathrm{Rb} 1$ in PAs precontracted with $\mathrm{KCl}(\mathrm{n}=12)$, ET-1 $(n=13)$ and Nif+ET-1 $(n=14)$. Vasorelaxation was expressed as percentage change in tension in the contractile response to $\mathrm{KCl}$ or $\mathrm{ET}-1$. * indicates $\mathrm{P}<0.05$ and ** indicates $\mathrm{P}<0.01$ compared to the $\mathrm{KCl}$ group. (E) The average time-course of $\mathrm{KCl}$-induced contraction generated from 9 different PAs. (F) The average time-course of ET-1 induced contraction generated from 9 different PAs.

Fig. 2. Effect of ginsenoside $\mathrm{Rb} 1$ pretreatment on ET-1-induced contraction in PAs of control, $\mathrm{CH}$-exposed and MCT-treated rats. (A-C) Representative traces of ET-1-induced contraction in PAs of control, $\mathrm{CH}$-exposed and MCT-treated rats with or without pretreated with ginsenoside Rb1. (D) The average values of ET-1-induced contraction in PAs of control ( $\mathrm{n}=12$ and 12), CH-exposed $(n=12$ and 12$)$ and MCT-treated $(n=13$ and 13) rats with or without pretreatment with ginsenoside $\mathrm{Rb} 1$. Contractile force was expressed as percentage of $60 \mathrm{mM} \mathrm{KCl-in-}$ duced contraction. (E) The average percent inhibition of ET-1-induced PA contraction caused by $\mathrm{Rb} 1$ in control, $\mathrm{CH}$-exposed and MCT-treated rats. ${ }^{* *}$ indicates $\mathrm{P}<0.01 \mathrm{com}$ pared to no pretreatment with ginsenoside $\mathrm{Rb} 1$. \# indicates $\mathrm{P}<0.05$, and \#\# indicates $\mathrm{P}<0.01$ compared to the control group.
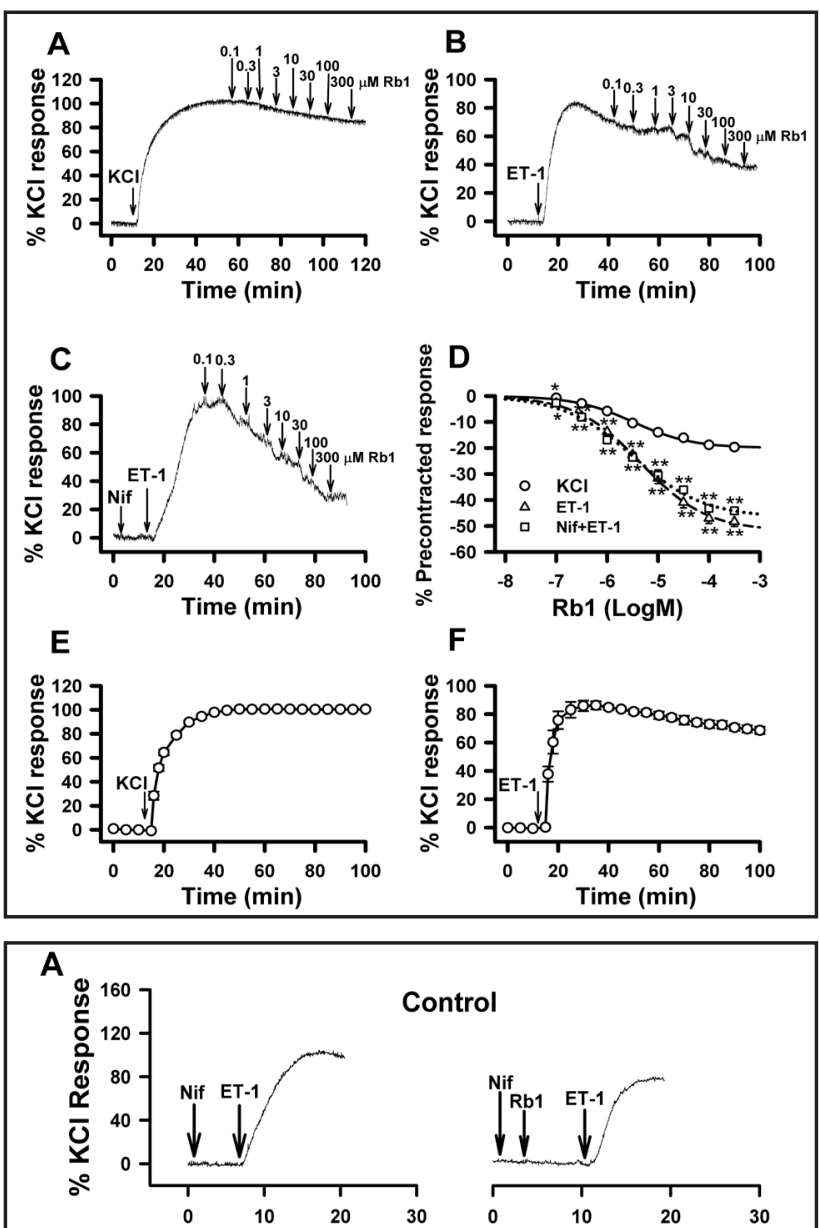

Control
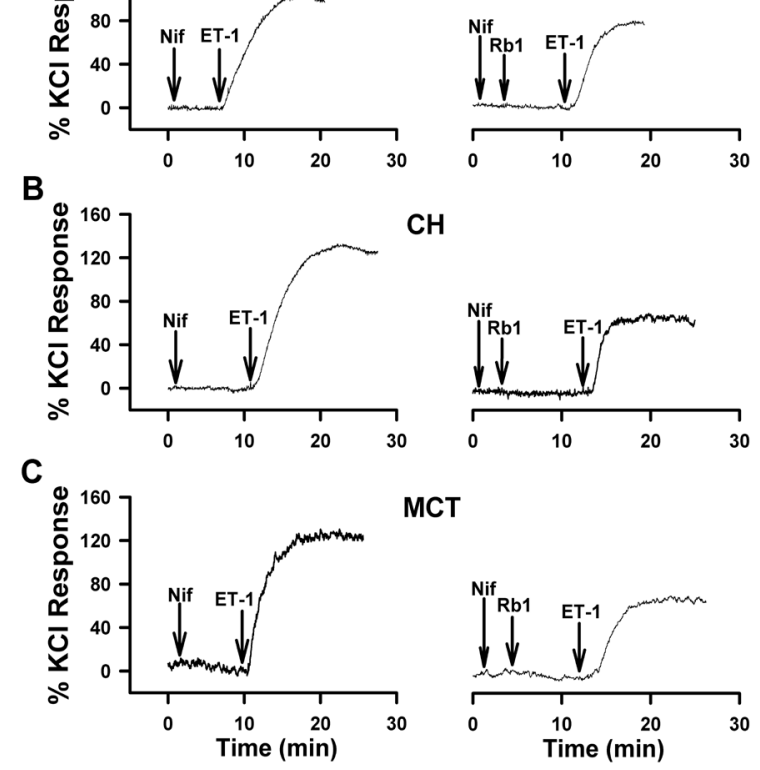

MCT

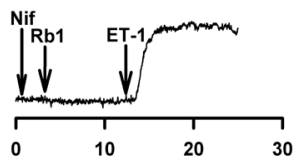

D
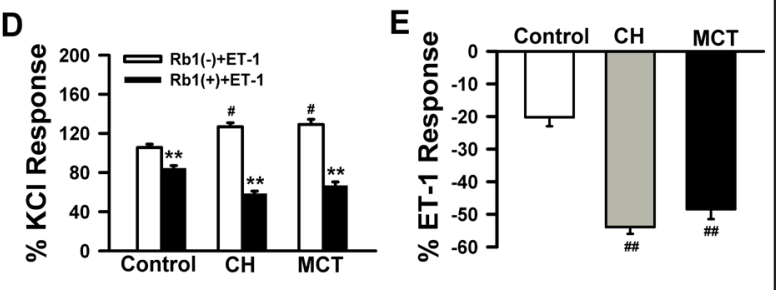

MCT induced PH rats $[34,36]$. To examine the possible involvement of SOCE, ginsenoside $\mathrm{Rb} 1$ dependent inhibition of ET-1 induced response was examined in the presence or absence of the SOCE inhibitor gadolinium $\left(\mathrm{Gd}^{3+}, 0.4 \mu \mathrm{M}\right)$ (Fig. 3). Ginsenoside Rb1 $(10 \mu \mathrm{M})$ 

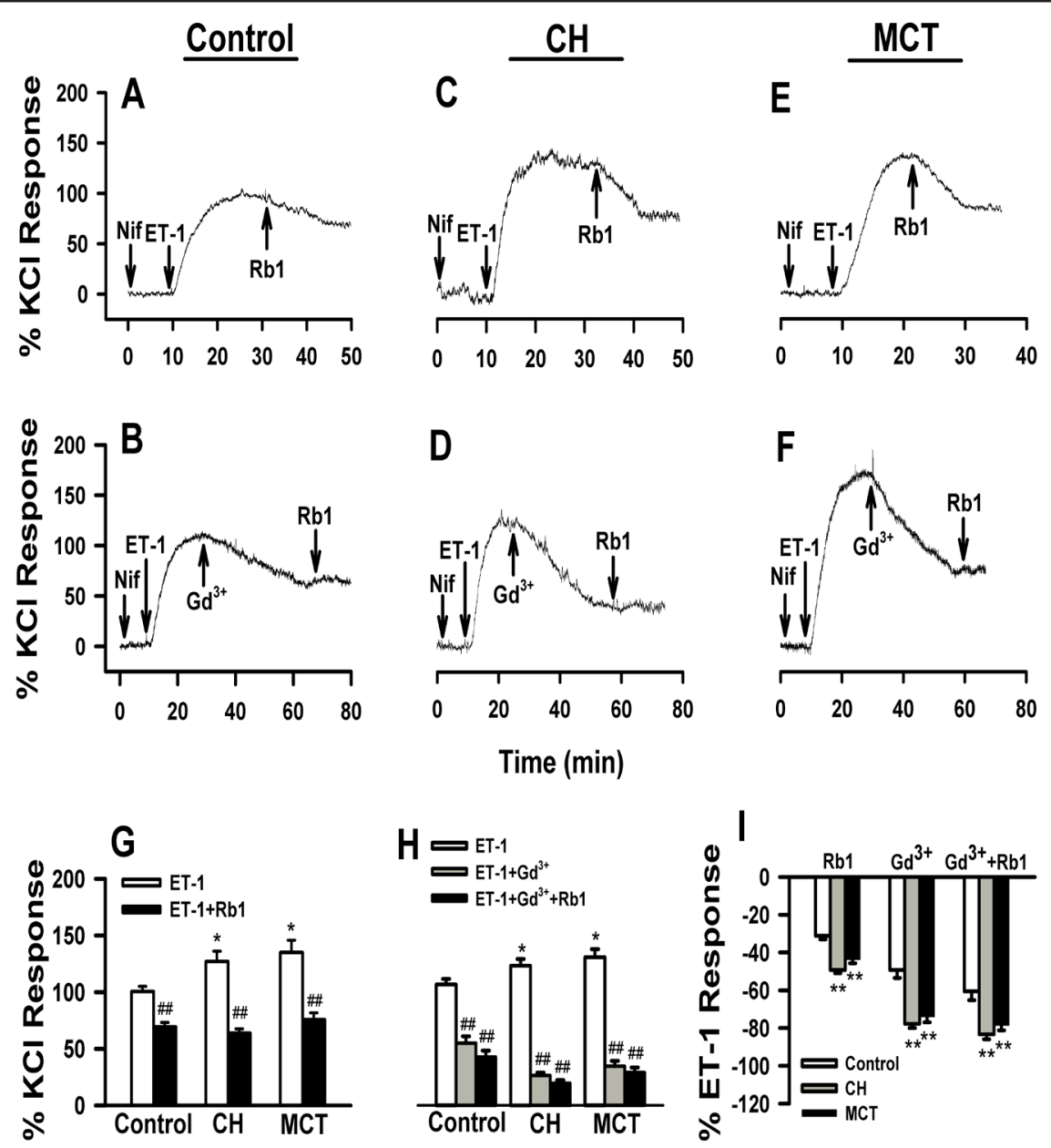

Fig. 3. Relaxation effect of ginsenoside $\mathrm{Rb} 1$ and $\mathrm{Gd}^{3+}$ on ET-1-precontracted PA of control, CH-exposed and MCT-treated rats. Typical traces of ginsenoside Rb1-induced vasorelaxation in ET-1 (10 nM) precontracted PAs of (A, B) control, (C, D) CH-exposed and (E, F) MCT-treated rats in the absence or presence of $0.4 \mu \mathrm{M}$ $\mathrm{Gd}^{3+}$. (G) The average values of ET-1 induced contraction before and after the addition of ginsenoside Rb1 $(10 \mu M)$ in PAs of control $(n=12), C H$-exposed $(n=12)$ and MCT-treated $(n=10)$ rats. Contractile force was expressed as percentage of $60 \mathrm{mM} \mathrm{KCl-induced} \mathrm{contraction.}(\mathrm{H})$ The average values of ET- 1 induced contraction with or without $\mathrm{Gd}^{3+}$ and $\mathrm{Gd}^{3+}+\mathrm{Rb} 1$ in PAs of control $(\mathrm{n}=12)$, CH-exposed $(\mathrm{n}=15)$ and MCT-treated $(\mathrm{n}=12)$ rats. (I) Percent relaxation of ET-1-induced contractions caused by $\mathrm{Rb} 1, \mathrm{Gd}^{3+}$ and $\mathrm{Gd}^{3+}+\mathrm{Rb} 1$ in $\mathrm{PAs}$ of control, CH-exposed and MCT-treated rats. * indicates $\mathrm{P}<0.05$ and ${ }^{* *}$ indicates $\mathrm{P}<0.01$ compared to the control. \#\# indicates $\mathrm{P}<0.01$ compared to the ET-1 group without treatment.

when applied to ET-1 precontracted PAs caused relaxation from $100.5 \pm 4.6 \%$ to $69.3 \pm 3.9 \%$ $(\mathrm{n}=12, \mathrm{p}<0.01)$ in control PAs (Fig. 3A). Application of $\mathrm{Gd}^{3+}(0.4 \mu \mathrm{M})$ also caused dramatic relaxation of ET-1 contracted PAs from $106.6 \pm 4.8 \%$ to $54.9 \pm 6.0 \%(n=12, \mathrm{p}<0.01)$, but further application of ginsenoside $\mathrm{Rb} 1$ failed to cause addition relaxation $(42.7 \pm 5.6 \%)$ (Fig. 3B). Similarly, application of $\mathrm{Gd}^{3+}$ relaxed ET-1 precontraction from $123.1 \pm 5.9 \%$ to $26.4 \pm 2.4 \%$ $(\mathrm{n}=15, \mathrm{p}<0.01)$ in PAs of $\mathrm{CH}$ rats; and from $130.6 \pm 7.1 \%$ to $34.5 \pm 4.7 \%(\mathrm{n}=12, \mathrm{p}<0.01)$ in MCT-treated rats (Fig. 3C-F). Application of ginsenoside Rb1 in the presence of $\mathrm{Gd}^{3+}$ did not cause further relaxation ( $\mathrm{CH}: 19.4 \pm 2.8 \%$; MCT: $28.9 \pm 4.4 \%$ ). Moreover, ginsenoside $\mathrm{Rb} 1, \mathrm{Gd}^{3+}$ and $\mathrm{Gd}^{3+}+$ ginsenoside $\mathrm{Rb} 1$ caused significant greater relaxation in CH-exposed and MCTtreated group compared to the control (Fig. 3I). These results suggest that ginsenoside Rb1 causes relaxation of ET-1 precontracted PA through inhibition of SOCE, and the inhibition is enhanced in PAs of PH rats. 
Fig. 4. Effect of ginsenoside $\mathrm{Rb} 1$ pretreatment on CPA-induced contraction in PAs of control, CH-exposed and MCT-treated rats. (A-C) Representative traces of CPA-induced contraction in PAs of control, $\mathrm{CH}$-exposed and MCT-treated rats with or without pretreated with ginsenoside Rb1. $10 \mu \mathrm{M}$ CPA was applied to PAs in $\mathrm{Ca}^{2+}$ free solution for $10 \mathrm{~min}$, and $2 \mathrm{mM} \mathrm{Ca}^{2+}$ was then reintroduced to allow store-operated $\mathrm{Ca}^{2+}$ entry. (D) The average values of CPA-induced contraction in PAs of control ( $n=11$ and 11), CH-exposed ( $n=10$ and 11) and MCT-treated $(n=12$ and 13) rats in the absence or presence of ginsenoside Rb1. Contractile force was expressed as percentage of $60 \mathrm{mM} \mathrm{KCl-induced} \mathrm{contraction.}$ (E) The average percent inhibition of CPA-induced contractions caused by $\mathrm{Rb} 1$ in PAs of control, $\mathrm{CH}$-exposed and MCT-treated rats. ${ }^{* *}$ indicates $\mathrm{P}<0.01$ compared to PAs without Rb1 pretreatment. \# indicates $\mathrm{P}<0.05$, and \#\# indicates $\mathrm{P}<0.01$ compared to the control group.

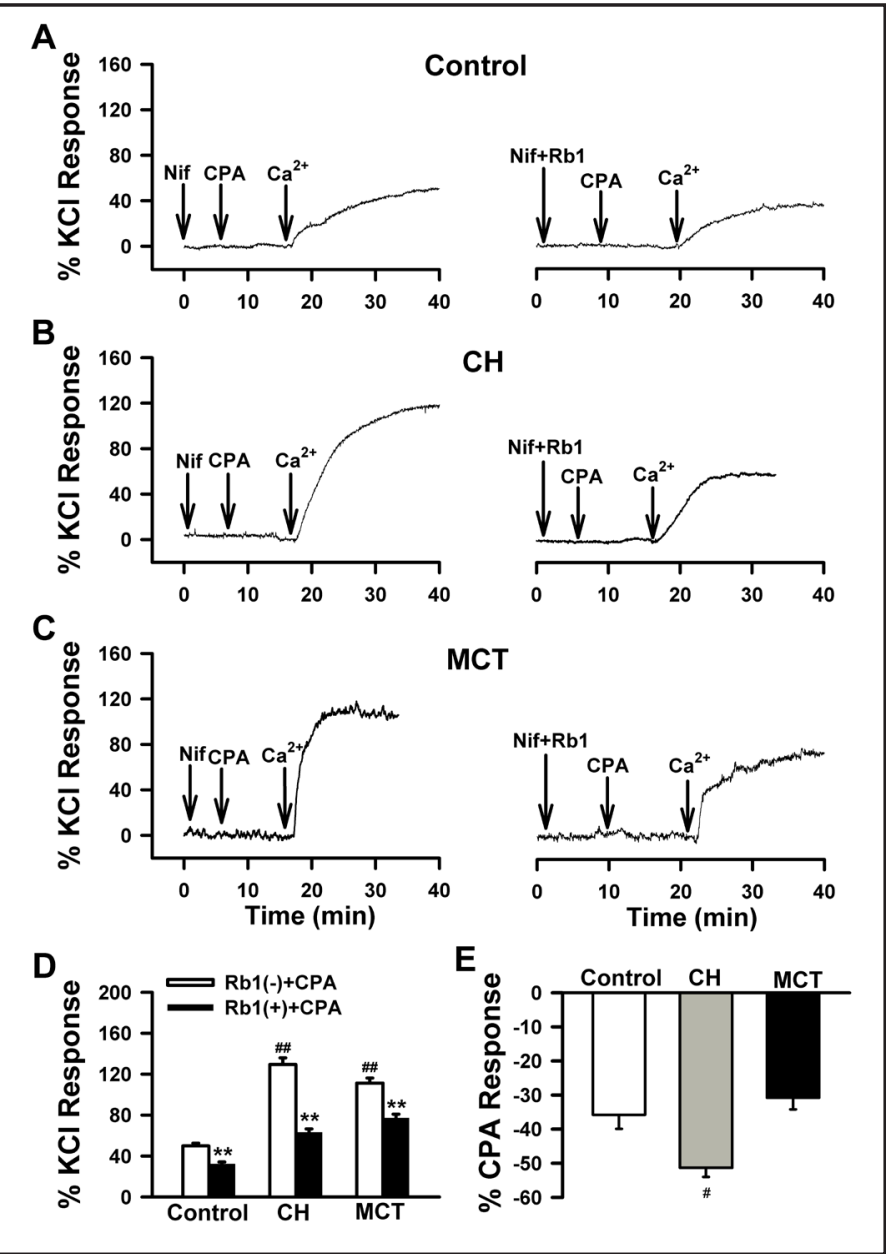

Effect of ginsenoside Rb1 on CPA-induced PA rings contraction in control, $\mathrm{CH}$-exposed and MCT-treated Rats

The effect of ginsenoside $\mathrm{Rb} 1$ on SOCE mediated PA contraction was further examined by depleting sarcoplasmic reticulum (SR) $\mathrm{Ca}^{2+}$ stores with cyclopiazonic acid (CPA). PA rings were exposed to $\mathrm{Ca}^{2+}$-free nifedipine $(3 \mu \mathrm{M})$ containing Tyrode solution followed by pretreatment with $10 \mu \mathrm{M}$ CPA for $10 \mathrm{~min}$. SOCE mediated contraction was initiated by readmission of $\mathrm{Ca}^{2+}$ to the external solution. Pretreatment with $10 \mu \mathrm{M}$ ginsenoside $\mathrm{Rb} 1$ significantly inhibited the contraction of PA rings induced by CPA (Fig. 4A and D)(control: $50.0 \pm 2.6 \%$ of $60 \mathrm{mM} \mathrm{KCl}$ response, $\mathrm{n}=11$; ginsenoside $\mathrm{Rb} 1$ treated: $32.1 \pm 2.1 \%, \mathrm{n}=11$, $\mathrm{p}<0.01$ ), indicating that ginsenoside $\mathrm{Rb} 1$ indeed inhibits SOCE.

CPA-induced contraction was examined in PAs of CH- and MCT-induced PH rats. The maximum contraction was $129.5 \pm 6.5 \%$ of $\mathrm{KCl}$-induced response $(\mathrm{n}=10, \mathrm{p}<0.01)$ in the $\mathrm{CH}$ group and $111.2 \pm 5.0 \%(\mathrm{n}=12, \mathrm{p}<0.01)$ in the MCT-treated groups. Ginsenoside $\mathrm{Rb} 1$ pretreatment caused significant inhibition of the CPA-induced contraction in PAs of $\mathrm{CH}$ $(63.0 \pm 3.5 \%, \mathrm{n}=11, \mathrm{p}<0.01)$ and MCT-treated $(77.0 \pm 3.8 \%, \mathrm{n}=13, \mathrm{p}<0.01)$ groups (Fig. 4B, C, and $\mathrm{D}$ ). The $\%$ inhibition of CPA-induced contraction by ginsenoside Rb1 was significantly greater $(\mathrm{P}<0.05)$ in $\mathrm{PAs}$ of $\mathrm{CH}$ rats compared to the control PAs (Fig. 4E).

Application of ginsenoside $(10 \mu \mathrm{M})$ directly to PAs precontracted with CPA (Fig. 5) caused time-dependent relaxation from $47.2 \pm 3.0 \%$ to $34.4 \pm 2.8 \% 60 \mathrm{mM} \mathrm{KCl}$ induced contraction $(\mathrm{n}=12, \mathrm{p}<0.01)$ in control PA, from $103.7 \pm 8.0 \%$ to $56.6 \pm 5.2 \%(\mathrm{n}=8, \mathrm{p}<0.01)$ in PAs of $\mathrm{CH}$ rats, and from $105.7 \pm 8.6 \%$ to $67.0 \pm 7.0 \%(\mathrm{n}=12, \mathrm{p}<0.01)$ in PAs of MCT-treated rats (Fig. $5 \mathrm{D})$. Relaxation induced by ginsenoside $\mathrm{Rb} 1$ was significant greater in PAs of $\mathrm{CH}$-exposed and MCT-treated rats than those of control rats (control: $-27.8 \pm 2.0 \%, \mathrm{n}=12 ; \mathrm{CH}:-45.5 \pm 2.3 \%$, 


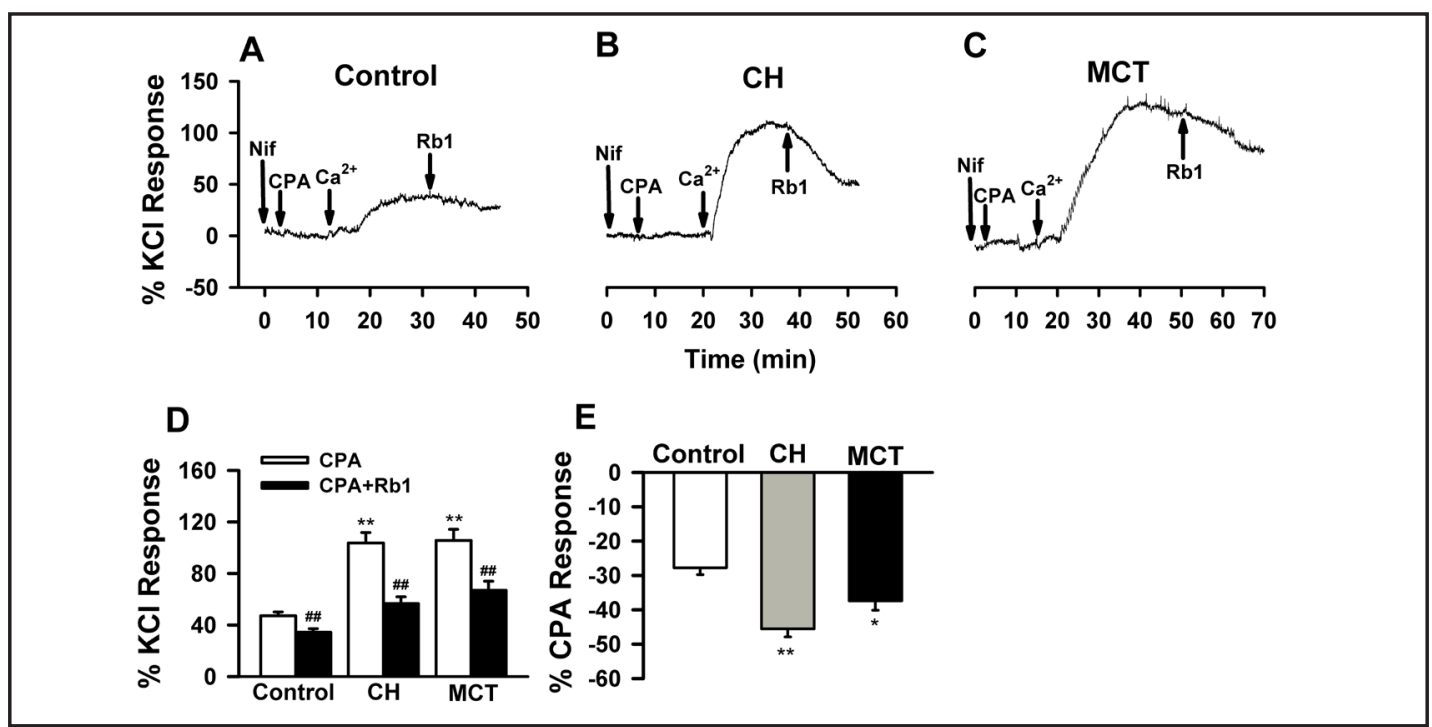

Fig. 5. Effect of ginsenoside Rb1 on CPA-precontracted PAs of control, $\mathrm{CH}$-exposed and MCT-treated rats. (AC) Typical traces of ginsenoside Rb1-induced vasorelaxation of CPA (10 $\mu \mathrm{M})$-induced contraction in PAs of control, CH-exposed and MCT-treated rats. (D) The average values of CPA-induced contraction before and after application of ginsenoside Rb1 in PAs of control ( $n=12)$, CH-exposed ( $n=8)$ and MCT-treated ( $n=12)$ rats. Contractile force was expressed as percentage of $60 \mathrm{mM} \mathrm{KCl}$-induced contraction. (E) The average percent relaxation of CPA-induced contractions caused by ginsenoside Rb1 in PAs of control ( $\mathrm{n}=12)$, $\mathrm{CH}$-exposed $(\mathrm{n}=8)$ and MCT-treated $(\mathrm{n}=12)$ rats. ${ }^{*}$ indicates $\mathrm{P}<0.05$ and ${ }^{* *}$ indicates $\mathrm{P}<0.01$ compared to the control group. \#\# indicates $\mathrm{P}<0.01$ compared to $\mathrm{CPA}$-induced contraction before application of $\mathrm{Rb} 1$.

$\mathrm{n}=8, \mathrm{p}<0.01$; MCT: $-37.4 \pm 2.8 \%, \mathrm{n}=12, \mathrm{p}<0.05$ ) (Fig. 5E). These results are consistent with the notion that ginsenoside Rb1 is an inhibitor of SOCE, and its influence on SOCE in PAs is enhanced during PH.

Effect of ginsenoside Rb1 on CPA-induced cation entry and Ca2+ Transients in PASMCs of Control, and $\mathrm{PH}$ rats

To examine directly the effect of ginsenoside Rb1 on SOCE, CPA-induced cation entry was quantified using the $\mathrm{Mn}^{2+}$ quenching technique in PASMCs (Fig. 6). In control PASMC pretreated with $10 \mu \mathrm{M}$ CPA for 10 mins, application of $500 \mu \mathrm{M} \mathrm{Mn}^{2+}$ caused significant reduction in fura-2 fluorescence. Pre-incubation of PASMCs with ginsenoside Rb1 for 10 min significantly reduced the maximal rate of $\mathrm{Mn}^{2+}$ quenching (control: $-1.24 \pm 0.14 \% / \mathrm{s}$, $\mathrm{n}=10$; Ginsenoside $\mathrm{Rb} 1:-0.54 \pm 0.10 \% / \mathrm{s}, \mathrm{n}=10, \mathrm{p}<0.01$ ). The rate of $\mathrm{Mn}^{2+}$ quenching was significantly enhanced in PASMCs of $\mathrm{CH}$ rats $(-2.40 \pm 0.34 \% / \mathrm{s}, \mathrm{n}=13, \mathrm{p}<0.05)$ and MCTtreated rats $(-2.47 \pm 0.33 \% / s, n=15, p<0.05)$ (Fig. 6A-D). Pretreatment with ginsenoside $\mathrm{Rb} 1$ abolished the enhanced rate of $\mathrm{Mn}^{2+}$ entry in PASMCs of $\mathrm{CH}(-0.77 \pm 0.06 \% / \mathrm{s}, \mathrm{n}=14, \mathrm{p}<0.01)$ and MCT-treated cells $(-0.57 \pm 0.10 \% / \mathrm{s}, \mathrm{n}=9, \mathrm{p}<0.01)$ (Fig. 6A-D).

The effect of ginsenoside Rb1 on SOCE was further examined by measuring CPA-induced $\mathrm{Ca}^{2+}$ transients (Fig. 7). $\mathrm{Ca}^{2+}$ transients was elicited in PASMCs treated with $10 \mu \mathrm{M}$ CPA for $10 \mathrm{~min}$ in $\mathrm{Ca}^{2+}$ free Tyrode solution (containing $0.1 \mathrm{mM}$ EGTA and $3 \mu \mathrm{M}$ nifedipine) followed by readmission of $\mathrm{Ca}^{2+}$ to external solution. The resting $\left[\mathrm{Ca}^{2+}\right]_{\mathrm{i}}$ and the amplitude of the $\mathrm{Ca}^{2+}$ influx transient was significantly higher in PASMCs of CH and MCT-treated groups compared to the control (control: $133.0 \pm 12.8 \mathrm{nM}, \mathrm{n}=14$; $\mathrm{CH}: 356.2 \pm 37.4 \mathrm{nM}, \mathrm{n}=12, \mathrm{p}<0.01$; MCT: 291.2 $\pm 36.2 \mathrm{nM}, \mathrm{n}=12, \mathrm{p}<0.01$ ) (Fig. 7D and F), whereas the CPA-induced $\mathrm{Ca}^{2+}$ release was similar in the three groups (Fig. 7E). Pretreatment with ginsenoside Rb1 (10 $\mu \mathrm{M}$ for $10 \mathrm{~min})$ reduced the elevated resting $\left[\mathrm{Ca}^{2+}\right]_{\mathrm{i}}$ in PASMCs of $\mathrm{CH}$ animals, but had no effect on the CPAinduced $\mathrm{Ca}^{2+}$ release. By contrast, ginsenoside $\mathrm{Rb} 1$ significantly reduced the CPA-induced $\mathrm{Ca}^{2+}$ influx transients in all three groups of PASMCs to a comparable levels (control: $80.9 \pm 9.2$

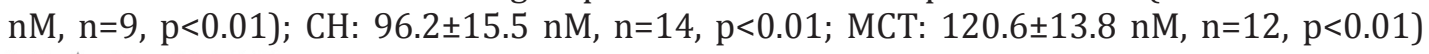


Fig. 6. Effect of ginsenoside $\mathrm{Rb} 1$ on CPA-induced cation entry measured by $\mathrm{Mn}^{2+}$ quenching in PASMCs of control, CH-exposed and MCT-treated rats. (A-C) The averaged time-course of $\mathrm{Mn}^{2+}$ quenching in PASMCs of control ( $\mathrm{n}=10$ and 10), CH- exposed ( $\mathrm{n}=13$ and 14) and MCT-treated ( $\mathrm{n}=15$ and 9$)$ rats with or without pretreatment with ginsenoside Rb1. (D) The maximum rate of quenching in PASMCs of control, CH-exposed and MCT-treated rats with or without ginsenoside $\mathrm{Rb} 1$ pretreatment. ${ }^{* *}$ indicates $\mathrm{P}<0.01$ comparing to the group without ginsenoside $\mathrm{Rb} 1$ treatment. \# indicates $\mathrm{P}<0.05$ compared to control group.

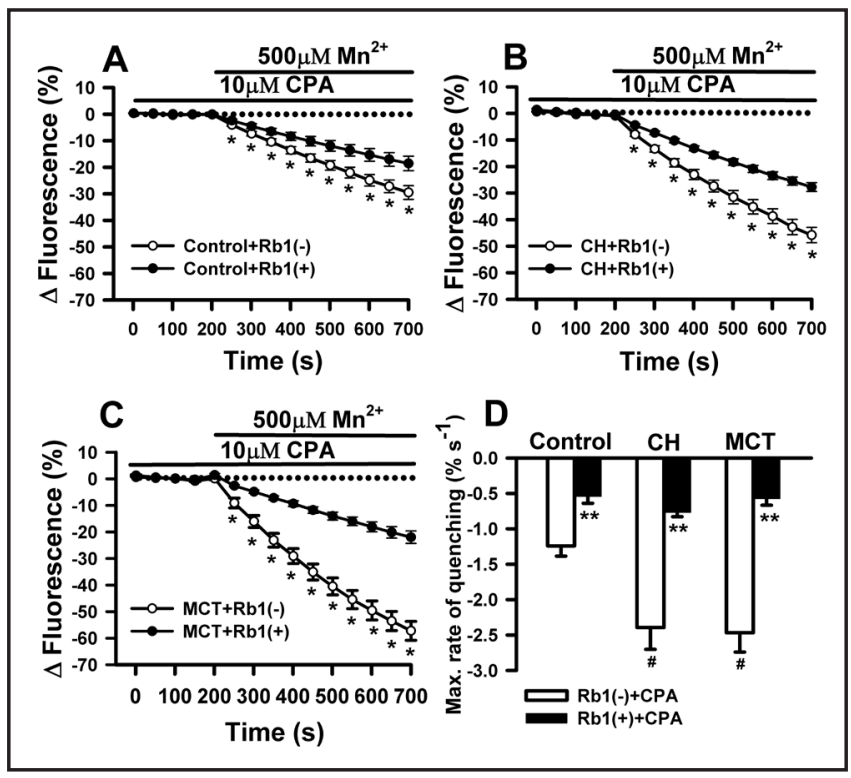

Fig. 7. Effect of ginsenoside $\mathrm{Rb} 1$ on CPA-induced $\mathrm{Ca}^{2+}$ transients in PASMCs of control, CH-exposed and MCT-treated rats. (A-C) Representative traces of CPA-induced $\mathrm{Ca}^{2+}$ transients in PASMCs of control, CH-exposed and MCT-treated rats with or without pretreatment with ginsenoside Rb1. (D-F) The average resting $\left[\mathrm{Ca}^{2+}\right]_{\mathrm{i}}$, peak changes in $\mathrm{Ca}^{2+}$ transients elicited by CPA-induced $\mathrm{Ca}^{2+}$ release and $\mathrm{Ca}^{2+}$ entry in PASMCs of control ( $\mathrm{n}=14$ and 9), CH-exposed ( $\mathrm{n}=12$ and 14$)$ and MCT-treated ( $\mathrm{n}=12$ and 12) rats in the presence or absence of ginsenoside $\mathrm{Rb} 1 . * *$ indicates $\mathrm{P}<0.01$ compared to PASMCs without ginsenoside $\mathrm{Rb} 1$ pretreatment. \#\# indicates $\mathrm{P}<0.01$ compared to control group.
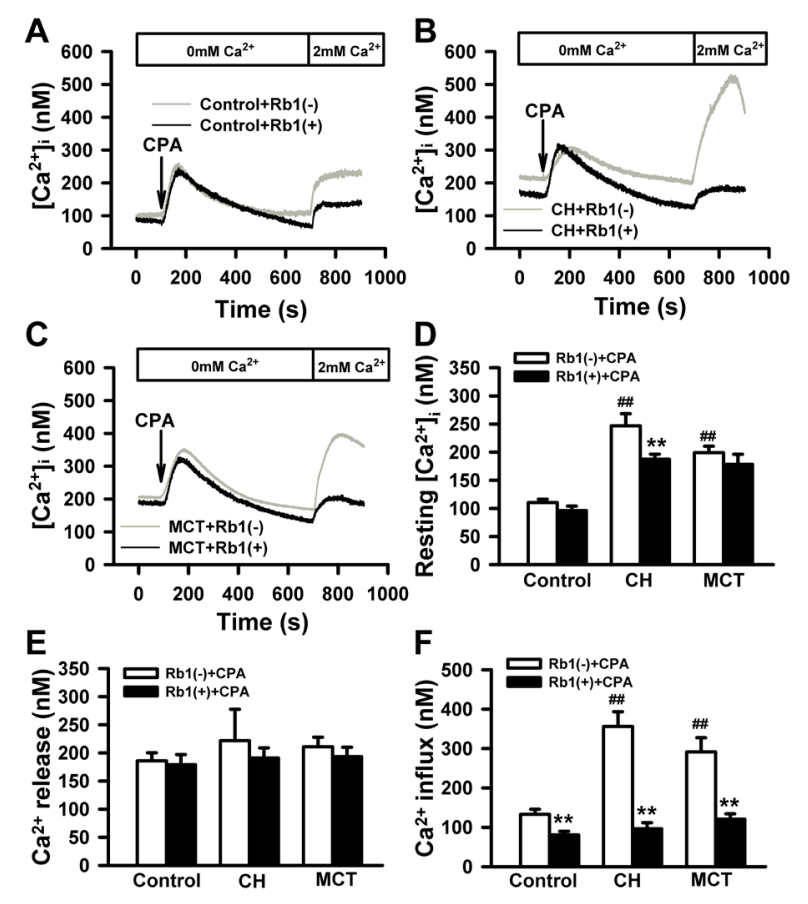

(Fig. 7F). These results clearly indicate that ginsenoside Rb1 inhibits SOCE in PASMCs, and abolishes the enhanced SOCE in PASMCs of CH and MCT-treated rats.

\section{Discussion}

The present study examined the effects of ginsenoside Rb1 on the agonist-induced contraction of end othelium denuded PA rings, and the CPA-induced $\mathrm{Ca}^{2+}$ transients and cation entry in PASMCs of normal rats and two different PH models. We found that ginsenoside Rb1 caused dramatic relaxation of ET-1-induced PA contraction. The ginsenoside Rb1-induced relaxation was not related to the inhibition of voltage-gated $\mathrm{Ca}^{2+}$ channel, but was mainly due to the inhibition of SOCE. This is based on several lines of evidence. First, ginsenoside 
Rb1 had a small effect on KCl-induced PA contraction, and its vasorelaxing effect on ET-1 induced contraction persisted in the presence of nifepidine. Second, the vasorelaxing effect of ginsenoside Rb1 on ET-1 mediated contraction was blocked by the SOCE inhibitor $\mathrm{Gd}^{3+}$. Third, ginsenoside Rb1 suppressed CPA-induced contraction of PA, and attenuated CPAactivated non-selective cation entry and $\mathrm{Ca}^{2+}$ transient in PASMCs. Furthermore, $\mathrm{CH}$ and MCT-induced PH enhanced the ET-1 and CPA-activated PA contraction, and CPA-activated cation entry and $\mathrm{Ca}^{2+}$ transients in PASMC. The enhancements of these responses were suppressed or abolished by ginsenoside $\mathrm{Rb} 1$. These results demonstrate for the first time that ginsenoside $\mathrm{Rb} 1$ is a functional inhibitor of SOCE, and it antagonizes the enhanced pulmonary vascular reactivity in $\mathrm{PH}$.

There is increasing evidence suggesting that ginsenoside $\mathrm{Rb} 1$ has therapeutic potential for the treatment of cardiovascular diseases [38]. Ginsenoside Rb1 has been shown to attenuate cellular hypertrophy, apoptosis and oxidative injury of cardiomyocytes [16-20]; and protect against ischemic-reperfusion injury [21,22], dilated cardiomyopathy [23] and right heart hypertrophy [24]. It exerts these cardioprotective effects through different mechanisms, for example by reducing $\left[\mathrm{Ca}^{2+}\right]_{i}$, enhancing the expression of eNOS and increasing nitric oxide production, attenuating reactive oxygen species and inhibiting the $\mathrm{Ca}^{2+}$-calcineurin signal transduction pathway in cardiac myocytes [17, 20, 21, 24, 39]. Ginsenoside Rb1 is also known to suppress intimal hyperplasia of carotid arteries after injury [11-13], promote endothelial nitric oxide production and protect against homocysteine-induced endothelial dysfunction via PI3Kinase/Akt pathways [10, 14], inhibit tumor necrosis factor- $\alpha$ evoked inflammatory responses and proliferation of vascular smooth muscle cells [15], and reverse antiretroviral therapy drug-induced pulmonary vasomotor dysfunction [40]. However, there is little information available on the vasoactive effects of ginsenocide $\mathrm{Rb} 1$, except a previous report showing ginsenoside $\mathrm{Rb} 1$ stimulates endothelial-dependent relaxation of mouse coronary arteries through e-NOS activation and NO production [41]. The present study, hence, revealed a novel direct relaxant effect of ginsenoside $\mathrm{Rb} 1$ on vascular smooth muscle.

Previous studies had shown that ginsenoside $\mathrm{Rb} 1$ causes partial inhibition of several types of voltage-gated $\mathrm{Ca}^{2+}$ channel in chromaffin cells [42], neurons [43, 44] and other expression systems [45]. But the inhibitory effect on voltage-gated $\mathrm{Ca}^{2+}$ channels is small, ranging from $10-20 \%$ at the maximal concentrations of 10-100 $\mu \mathrm{M}$ [42-44]. This is comparable to the small vasorelaxing effect of ginsenoside $\mathrm{Rb} 1$ on the KCl-induced PA contraction. Since ET-1 induced PA contraction is only partially mediated by the L-type $\mathrm{Ca}^{2+}$ channels [37], the small inhibition on the voltage-gated $\mathrm{Ca}^{2+}$ channel could not account for the robust vasorelaxing effect of ginsenoside Rb1. Indeed, ginsenoside Rb1 caused similar relaxation in PA precontracted with ET-1 in the absence or presence of nifedipine, suggesting the vasorelaxing effect is unrelated to the inhibition of voltage-gated $\mathrm{Ca}^{2+}$ channel.

Our present results clearly suggest that ginsenoside Rb1 exerts its vasorelaxing effect on rat PAs through inhibition of SOCE. ET-1-induced contraction of PA is mediated in part through SOCE [36], which can be effectively suppressed by the SOCE blockers $\mathrm{Gd}^{3+}$, $\mathrm{La}^{3+}$, SKF96365 and BTP-2. The complete abolition of the vasorelaxant effect of ginsenoside Rb1 in the presence of a low concentration of $\mathrm{Gd}^{3+}$ is congruent with SOCE inhibition. This is substantiated by three different methods of measuring CPA-induced contraction of PA, CPA-induced $\mathrm{Ca}^{2+}$ influx transients and $\mathrm{Mn}^{2+}$ quenching of Fura-2 fluorescence in PASMCs, which all showed consistent attenuation of SOCE by ginsenoside Rb1. SOCE has been well characterized in many different cell types including PASMCs. It is initiated by $\mathrm{Ca}^{2+}$ release from SR, leading to $\mathrm{SR} \mathrm{Ca}^{2+}$ depletion, oligomerization and translocation of stromal interaction molecule (STIM) to the SR-plasma membrane junctions to couple with the store-operated $\mathrm{Ca}^{2+}$ channels (SOCCs)[46-48]. Previous studies from several laboratories including ours have identified the canonical transient receptor potential 1 (TRPC1) and Orai1 as the major components of SOCC in PASMCs [34, 49-53]; and other TRPC subtypes and non-selective cation channels may be also involved [54-56]. Inhibition of SOCE by ginsenoside Rb1 is not related to the suppression of SR $\mathrm{Ca}^{2+}$ release, because the CPA-induced $\mathrm{Ca}^{2+}$ release was unaltered in the presence of ginsenoside Rb1. It may inhibit SOCE by suppressing STIM activation and/or by 
inhibiting the TRPC1/Orai channels of PASMCs. But, whether ginsenoside Rb1 acts directly through interactions with STIM1, TRPC1 and Orai1, or indirectly through other signaling pathways is unclear. Recent evidence has indicated that SOCE can be regulated by reactive oxygen species (ROS) through redox-dependent modification of STIM and Orai proteins [57]. Since ginsenoside Rb1 is known to reduce oxidative stress in different cells and tissues [17, $27,58,59]$, it is possible that it modulates SOCE through a ROS-related mechanism.

It is important to note that the efficacy of ginsenoside Rb1 for the inhibition of ET-1induced response and SOCE was increased in PAs of PH rats. Ginsenoside Rb1 completely reversed the enhanced ET-1 induced contraction in PAs, and normalized the enhanced CPAinduced $\mathrm{Ca}^{2+}$ and cation entry in PASMCs of $\mathrm{CH}$ and MCT-treated rats. This is similar to our previous finding that ET-1-induced contraction in PA and $\mathrm{Ca}^{2+}$ response in PASMC of MCTtreated rats are more susceptible to the inhibition by SOCE blockers [36], and is consistent with the notion that the enhanced ET-1 induced response is mediated by upregulation of SOCE in PASMCs during PH. The finding of ginsenoside Rb1 as an effective inhibitor of ET-1 and SOCE raises the intriguing possibility that the ginsenoside may be considered as a potential therapeutic agent for the treatment of PH. ET-1 has been implicated as an important factor in the development of PH. Its circulating level is increased, its receptor density in PA is upregulated and vasoconstrictory effect is enhanced during $\mathrm{PH}$; and antagonists of ET-receptors can effectively prevent and reverse PH [60-66]. Enhanced SOCE has been reported in many different models of experimental PH, including CHPH [34, 67], monocrotaline-induced PH [36] and cigarette smoke-induced PH [68], and in patients of idiopathic pulmonary arterial hypertension (IPAH)[69-71]. It contributes to the elevated $\left[\mathrm{Ca}^{2+}\right]_{\mathrm{i}}$ of PASMCs, increased pulmonary vascular tone, enhanced vasoreactivity and vascular remodeling, and plays a crucial pathogenic role in $\mathrm{PH}[28,34,54,72]$. Our observation that ginsenoside $\mathrm{Rb} 1$ reduces the elevated resting $\left[\mathrm{Ca}^{2+}\right]_{\mathrm{i}}$ in PASMCs of $\mathrm{CH}$ rat is consistent with inhibition of the enhanced SOCE in resting CH PASMCs. Our results also indicate that ginsenoside Rb1 inhibits the enhanced pulmonary vasoreactivity in two mechanistically different forms of PH. Hence, ginsenoside Rb1 by inhibiting ET-1 induced responses and SOCE may be effective for alleviating PH. Indeed, this is supported by the previous study showing ginsenoside Rb1 protected and reversed the MCT-induced right heart hypertrophy [24]. Future experiments will be needed for examining the effects of ginsenoside Rb1 on pulmonary vascular remodeling. This will further establish the therapeutic potentials of the ginsenoside in $\mathrm{PH}$, and may provide an alternative treatment for the dreadful disease.

\section{Acknowledgements}

This work was supported by grants from the National Natural Science Foundation of China (NSFC 31171104 and NSFC31371165), Key Program of Scientific Research of Fujian Medical University (09ZD010) and Fujian Province "Hundred Experts Award".

\section{References}

1 Simonneau G, Gatzoulis MA, Adatia I, Celermajer D, Denton C, Ghofrani A, Gomez Sanchez MA, Krishna Kumar R, Landzberg M, Machado RF, Olschewski H, Robbins IM, Souza R: Updated clinical classification of pulmonary hypertension. J Am Coll Cardiol 2013;62:D34-41.

2 Humbert M, Morrell NW, Archer SL, Stenmark KR, MacLean MR, Lang IM, Christman BW, Weir EK, Eickelberg O, Voelkel NF, Rabinovitch M: Cellular and molecular pathobiology of pulmonary arterial hypertension. J Am Coll Cardiol 2004;43:13S-24S.

3 Firth AL, Won JY, Park WS: Regulation of $\mathrm{ca}(2+)$ signaling in pulmonary hypertension. Korean J Physiol Pharmacol 2013;17:1-8. 


\section{Cellular Physiology Cell Physiol Biochem 2015;35:1467-1481 \begin{tabular}{l|l} 
and Biochemisty $\begin{array}{l}\text { DOI: 10.1159/000373966 } \\
\text { Published online: March 12, } 2015\end{array}$ & $\begin{array}{l}\text { C 2015 S. Karger AG, Basel } \\
\text { www.karger.com/cpb }\end{array}$ \\
\hline
\end{tabular} \\ Wang et al.: Ginsenoside Rb1 Attenuates Store-Operated Calcium Entry}

4 Humbert M, Sitbon O, Chaouat A, Bertocchi M, Habib G, Gressin V, Yaici A, Weitzenblum E, Cordier JF, Chabot F, Dromer C, Pison C, Reynaud-Gaubert M, Haloun A, Laurent M, Hachulla E, Cottin V, Degano B, Jais X, Montani D, Souza R, Simonneau G: Survival in patients with idiopathic, familial, and anorexigenassociated pulmonary arterial hypertension in the modern management era. Circulation 2010;122:156163.

5 Humbert M, Sitbon O, Yaici A, Montani D, O'Callaghan DS, Jais X, Parent F, Savale L, Natali D, Gunther S, Chaouat A, Chabot F, Cordier JF, Habib G, Gressin V, Jing ZC, Souza R, Simonneau G: Survival in incident and prevalent cohorts of patients with pulmonary arterial hypertension. Eur Respir J 2010;36:549-555.

6 Quan HY, Yuan HD, Jung MS, Ko SK, Park YG, Chung SH: Ginsenoside Re lowers blood glucose and lipid levels via activation of AMP-activated protein kinase in HepG2 cells and high-fat diet fed mice. Int J Mol Med 2012;29:73-80.

7 Wei X, Chen J, Su F, Su X, Hu T, Hu S: Stereospecificity of ginsenoside Rg3 in promotion of the immune response to ovalbumin in mice. Int Immunol 2012;24:465-471.

8 Kim HJ, Kim P, Shin CY: A comprehensive review of the therapeutic and pharmacological effects of ginseng and ginsenosides in central nervous system. J Ginseng Res 2013;37:8-29.

9 Attele AS, Wu JA, Yuan CS: Ginseng pharmacology: multiple constituents and multiple actions. Biochem Pharmacol 1999;58:1685-1693.

10 Lan TH, Xu ZW, Wang Z, Wu YL, Wu WK, Tan HM: Ginsenoside Rb1 prevents homocysteine-induced endothelial dysfunction via PI3K/Akt activation and PKC inhibition. Biochem Pharmacol 2011;82:148-155.

11 Chai H, Dong Y, Wang X, Zhou W: Ginsenoside Rb1 attenuates homocysteine-augmented guidewire injuryinduced intimal hyperplasia in mice. J Surg Res 2009;157:193-198.

12 Zhang S, Deng J, Gao Y, Yang DL, Gong QH, Huang XN: Ginsenoside Rb(1) inhibits the carotid neointimal hyperplasia induced by balloon injury in rats via suppressing the phenotype modulation of vascular smooth muscle cells. Eur J Pharmacol 2012;685:126-132.

13 Chai H, Schultz G, Aghaie K, Zhou W: In vivo assessment of the effects of ginsenoside Rb1 on intimal hyperplasia in ApoE knockout mice. J Surg Res 2010;162:26-32.

14 Yu J, Eto M, Akishita M, Kaneko A, Ouchi Y, Okabe T: Signaling pathway of nitric oxide production induced by ginsenoside Rb1 in human aortic endothelial cells: a possible involvement of androgen receptor. Biochem Biophys Res Commun 2007;353:764-769.

15 Li QY, Chen L, Fu WH, Li ZD, Wang B, Shi XJ, Zhong MK: Ginsenoside Rb1 inhibits proliferation and inflammatory responses in rat aortic smooth muscle cells. J Agric Food Chem 2011;59:6312-6318

16 Wang XF, Liu XJ, Zhou QM, Du J, Zhang TL, Lu YY, Su SB: Ginsenoside rb1 reduces isoproterenol-induced cardiomyocytes apoptosis in vitro and in vivo. Evid Based Complement Alternat Med 2013;2013:454389.

17 Li J, Shao ZH, Xie JT, Wang CZ, Ramachandran S, Yin JJ, Aung H, Li CQ Qin G, Vanden Hoek T, Yuan CS: The effects of ginsenoside Rb1 on JNK in oxidative injury in cardiomyocytes. Arch Pharm Res 2012;35:12591267.

18 Kong HL, Li ZQ, Zhao YJ, Zhao SM, Zhu L, Li T, Fu Y, Li HJ: Ginsenoside Rb1 protects cardiomyocytes against $\mathrm{CoCl2}$-induced apoptosis in neonatal rats by inhibiting mitochondria permeability transition pore opening. Acta Pharmacol Sin 2010;31:687-695.

19 Kong HL, Wang JP, Li ZQ, Zhao SM, Dong J, Zhang WW: Anti-hypoxic effect of ginsenoside Rbl on neonatal rat cardiomyocytes is mediated through the specific activation of glucose transporter-4 ex vivo. Acta Pharmacol Sin 2009;30:396-403.

20 Jiang QS, Huang XN, Yang GZ, Jiang XY, Zhou QX: Inhibitory effect of ginsenoside Rb1 on calcineurin signal pathway in cardiomyocyte hypertrophy induced by prostaglandin F2alpha. Acta Pharmacol Sin 2007;28:1149-1154.

21 Xia R, Zhao B, Wu Y, Hou JB, Zhang L, Xu JJ, Xia ZY: Ginsenoside Rb1 preconditioning enhances eNOS expression and attenuates myocardial ischemia/reperfusion injury in diabetic rats. J Biomed Biotechnol 2011;2011:767930.

22 Wang Z, Li M, Wu WK, Tan HM, Geng DF: Ginsenoside Rb1 preconditioning protects against myocardial infarction after regional ischemia and reperfusion by activation of phosphatidylinositol-3-kinase signal transduction. Cardiovasc Drugs Ther 2008;22:443-452.

23 Zhao H, Lv D, Zhang W, Dong W, Feng J, Xiang Z, Huang L, Qin C, Zhang L: Ginsenoside-Rb1 attenuates dilated cardiomyopathy in cTnT(R141W) transgenic mouse. J Pharmacol Sci 2010;112:214-222. 


\section{Cellular Physiology Cell Physiol Biochem 2015;35:1467-1481 \begin{tabular}{c|c|c|}
\hline DOI: 10.1159/000373966 & C 2015 S. Karger AG, Basel
\end{tabular} www.karger.com/cpb \\ Wang et al.: Ginsenoside Rb1 Attenuates Store-Operated Calcium Entry}

24 Jiang QS, Huang XN, Dai ZK, Yang GZ, Zhou QX, Shi JS, Wu Q: Inhibitory effect of ginsenoside Rb1 on cardiac hypertrophy induced by monocrotaline in rat. J Ethnopharmacol 2007;111:567-572.

25 Stenmark KR, Meyrick B, Galie N, Mooi WJ, McMurtry IF: Animal models of pulmonary arterial hypertension: the hope for etiological discovery and pharmacological cure. Am J Physiol Lung Cell Mol Physiol 2009;297:L1013-1032.

26 Shimoda LA, Sham JS, Sylvester JT: Altered pulmonary vasoreactivity in the chronically hypoxic lung. Physiol Res 2000;49:549-560.

27 Liu DH, Chen YM, Liu Y, Hao BS, Zhou B, Wu L, Wang M, Chen L, Wu WK, Qian XX: Rb1 protects endothelial cells from hydrogen peroxide-induced cell senescence by modulating redox status. Biol Pharm Bull 2011;34:1072-1077.

28 Xia Y, Yang XR, Fu Z, Paudel O, Abramowitz J, Birnbaumer L, Sham JS: Classical transient receptor potential 1 and 6 contribute to hypoxic pulmonary hypertension through differential regulation of pulmonary vascular functions. Hypertension 2014;63:173-180.

29 Sun H, Xia Y, Paudel O, Yang XR, Sham JS: Chronic hypoxia-induced upregulation of Ca2+-activated Clchannel in pulmonary arterial myocytes: a mechanism contributing to enhanced vasoreactivity. J Physiol 2012;590:3507-3521.

30 MacLean MR, Morecroft I: Increased contractile response to 5-hydroxytryptamine1-receptor stimulation in pulmonary arteries from chronic hypoxic rats: role of pharmacological synergy. Br J Pharmacol 2001;134:614-620.

31 MacLean MR, Sweeney G, Baird M, McCulloch KM, Houslay M, Morecroft I: 5-Hydroxytryptamine receptors mediating vasoconstriction in pulmonary arteries from control and pulmonary hypertensive rats. Br J Pharmacol 1996;119:917-930.

32 Liu JQ, Erbynn EM, Folz RJ: Chronic hypoxia-enhanced murine pulmonary vasoconstriction: role of superoxide and gp91phox. Chest 2005;128:594S-596S.

33 Liu JQ, Zelko IN, Erbynn EM, Sham JS, Folz RJ: Hypoxic pulmonary hypertension: role of superoxide and NADPH oxidase (gp91phox). Am J Physiol Lung Cell Mol Physiol 2006;290:L2-10.

34 Lin MJ, Leung GP, Zhang WM, Yang XR, Yip KP, Tse CM, Sham JS: Chronic hypoxia-induced upregulation of store-operated and receptor-operated $\mathrm{Ca} 2+$ channels in pulmonary arterial smooth muscle cells: a novel mechanism of hypoxic pulmonary hypertension. Circ Res 2004;95:496-505.

35 Liu XR, Liu Q, Chen GY, Hu Y, Sham JS, Lin MJ: Down-regulation of TRPM8 in pulmonary arteries of pulmonary hypertensive rats. Cell Physiol Biochem 2013;31:892-904.

36 Liu XR, Zhang MF, Yang N, Liu Q, Wang RX, Cao YN, Yang XR, Sham JS, Lin MJ: Enhanced store-operated $\mathrm{Ca}(2)+$ entry and TRPC channel expression in pulmonary arteries of monocrotaline-induced pulmonary hypertensive rats. Am J Physiol Cell Physiol 2012;302:C77-87.

37 Shimoda LA, Sham JS, Shimoda TH, Sylvester JT: L-type $\mathrm{Ca}(2+)$ channels, resting [Ca(2+)](i), and ET1-induced responses in chronically hypoxic pulmonary myocytes. Am J Physiol Lung Cell Mol Physiol 2000;279:L884-894.

38 Yang X, Xiong X, Wang H, Wang J: Protective effects of panax notoginseng saponins on cardiovascular diseases: a comprehensive overview of experimental studies. Evid Based Complement Alternat Med 2014;2014:204840.

39 Wu Y, Xia ZY, Dou J, Zhang L, Xu JJ, Zhao B, Lei S, Liu HM: Protective effect of ginsenoside Rb1 against myocardial ischemia/reperfusion injury in streptozotocin-induced diabetic rats. Mol Biol Rep 2011;38:4327-4335.

40 Wang X, Chai H, Lin PH, Yao Q, Chen C: Roles and mechanisms of human immunodeficiency virus protease inhibitor ritonavir and other anti-human immunodeficiency virus drugs in endothelial dysfunction of porcine pulmonary arteries and human pulmonary artery endothelial cells. Am J Pathol 2009;174:771781.

41 Pan C, Huo Y, An X, Singh G, Chen M, Yang Z, Pu J, Li J: Panax notoginseng and its components decreased hypertension via stimulation of endothelial-dependent vessel dilatation. Vascul Pharmacol 2012;56:150158.

42 Kim HS, Lee JH, Goo YS, Nah SY: Effects of ginsenosides on Ca2+ channels and membrane capacitance in rat adrenal chromaffin cells. Brain Res Bull 1998;46:245-251.

43 Nah SY, Park HJ, McCleskey EW: A trace component of ginseng that inhibits Ca2+ channels through a pertussis toxin-sensitive G protein. Proc Natl Acad Sci U S A 1995;92:8739-8743. 


\section{Cellular Physiology Cell Physiol Biochem 2015;35:1467-1481 \begin{tabular}{l|l|l} 
DOI: $10.1159 / 000373966$ & (C) 2015 S. Karger AG, Basel
\end{tabular} \\ Wang et al.: Ginsenoside Rb1 Attenuates Store-Operated Calcium Entry}

44 Lin ZY, Chen LM, Zhang J, Pan XD, Zhu YG, Ye QY, Huang HP, Chen XC: Ginsenoside Rb1 selectively inhibits the activity of L-type voltage-gated calcium channels in cultured rat hippocampal neurons. Acta Pharmacol Sin 2012;33:438-444.

45 Lee JH, Jeong SM, Kim JH, Lee BH, Yoon IS, Choi SH, Lee SM, Park YS, Kim SS, Kim HC, Lee BY, Nah SY: Effects of ginsenosides and their metabolites on voltage-dependent $\mathrm{Ca}(2+)$ channel subtypes. Mol Cells 2006;21:52-62.

46 Zhang SL, Yu Y, Roos J, Kozak JA, Deerinck TJ, Ellisman MH, Stauderman KA, Cahalan MD: STIM1 is a Ca2+ sensor that activates CRAC channels and migrates from the Ca2+ store to the plasma membrane. Nature 2005;437:902-905.

47 Roos J, DiGregorio PJ, Yeromin AV, Ohlsen K, Lioudyno M, Zhang S, Safrina O, Kozak JA, Wagner SL, Cahalan MD, Velicelebi G, Stauderman KA: STIM1, an essential and conserved component of store-operated Ca2+ channel function. J Cell Biol 2005;169:435-445.

48 Liou J, Kim ML, Heo WD, Jones JT, Myers JW, Ferrell JE, Jr., Meyer T: STIM is a Ca2+ sensor essential for Ca2+-store-depletion-triggered Ca2+ influx. Curr Biol 2005;15:1235-1241.

49 Sweeney M, Yu Y, Platoshyn O, Zhang S, McDaniel SS, Yuan JX: Inhibition of endogenous TRP1 decreases capacitative Ca2+ entry and attenuates pulmonary artery smooth muscle cell proliferation. Am J Physiol Lung Cell Mol Physiol 2002;283:L144-155.

50 Ng LC, O'Neill KG, French D, Airey JA, Singer CA, Tian H, Shen XM, Hume JR: TRPC1 and Orai1 interact with STIM1 and mediate capacitative $\mathrm{Ca}(2+)$ entry caused by acute hypoxia in mouse pulmonary arterial smooth muscle cells. Am J Physiol Cell Physiol 2012;303:C1156-1172.

51 Ng LC, Ramduny D, Airey JA, Singer CA, Keller PS, Shen XM, Tian H, Valencik M, Hume JR: Orai1 interacts with STIM1 and mediates capacitative Ca2+ entry in mouse pulmonary arterial smooth muscle cells. Am J Physiol Cell Physiol 2010;299:C1079-1090.

52 Kunichika N, Yu Y, Remillard CV, Platoshyn O, Zhang S, Yuan JX: Overexpression of TRPC1 enhances pulmonary vasoconstriction induced by capacitative Ca2+ entry. Am J Physiol Lung Cell Mol Physiol 2004;287:L962-969.

53 Ogawa A, Firth AL, Smith KA, Maliakal MV, Yuan JX: PDGF enhances store-operated Ca2+ entry by upregulating STIM1/Orai1 via activation of Akt/mTOR in human pulmonary arterial smooth muscle cells. Am J Physiol Cell Physiol 2012;302:C405-411.

54 Remillard CV, Yuan JX: TRP channels, CCE, and the pulmonary vascular smooth muscle. Microcirculation 2006;13:671-692.

55 Jernigan NL, Herbert LM, Walker BR, Resta TC: Chronic hypoxia upregulates pulmonary arterial ASIC1: a novel mechanism of enhanced store-operated Ca2+ entry and receptor-dependent vasoconstriction. Am J Physiol Cell Physiol 2012;302:C931-940.

56 Jernigan NL, Paffett ML, Walker BR, Resta TC: ASIC1 contributes to pulmonary vascular smooth muscle store-operated Ca(2+) entry. Am J Physiol Lung Cell Mol Physiol 2009;297:L271-285.

57 Nunes P, Demaurex N: Redox regulation of store-operated Ca2+ entry. Antioxid Redox Signal 2014;21:915932.

58 Lu JM, Weakley SM, Yang Z, Hu M, Yao Q Chen C: Ginsenoside Rb1 directly scavenges hydroxyl radical and hypochlorous acid. Curr Pharm Des 2012;18:6339-6347.

59 Ohashi R, Yan S, Mu H, Chai H, Yao Q Lin PH, Chen C: Effects of homocysteine and ginsenoside Rb1 on endothelial proliferation and superoxide anion production. J Surg Res 2006;133:89-94.

60 Yu J, Taylor L, Wilson J, Comhair S, Erzurum S, Polgar P: Altered expression and signal transduction of endothelin-1 receptors in heritable and idiopathic pulmonary arterial hypertension. J Cell Physiol 2013;228:322-329.

61 Coe Y, Haleen SJ, Welch KM, Liu YA, Coceani F: The endothelin A receptor antagonists PD 156707 (CI1020) and PD 180988 (CI-1034) reverse the hypoxic pulmonary vasoconstriction in the perinatal lamb. J Pharmacol Exp Ther 2002;302:672-680.

62 Li H, Elton TS, Chen YF, Oparil S: Increased endothelin receptor gene expression in hypoxic rat lung. Am J Physiol 1994;266:L553-560.

63 Rondelet B, Kerbaul F, Motte S, van Beneden R, Remmelink M, Brimioulle S, McEntee K, Wauthy P, Salmon I, Ketelslegers JM, Naeije R: Bosentan for the prevention of overcirculation-induced experimental pulmonary arterial hypertension. Circulation 2003;107:1329-1335. 


\section{Cellular Physiology Cell Physiol Biochem 2015;35:1467-1481

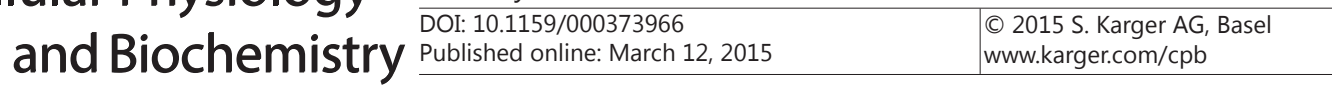 \\ Wang et al.: Ginsenoside Rb1 Attenuates Store-Operated Calcium Entry}

64 Chen SJ, Chen YF, Meng QC, Durand J, Dicarlo VS, Oparil S: Endothelin-receptor antagonist bosentan prevents and reverses hypoxic pulmonary hypertension in rats. J Appl Physiol 1995;79:2122-2131.

65 DiCarlo VS, Chen SJ, Meng QC, Durand J, Yano M, Chen YF, Oparil S: ETA-receptor antagonist prevents and reverses chronic hypoxia-induced pulmonary hypertension in rat. Am J Physiol 1995;269:L690-697.

66 Li H, Chen SJ, Chen YF, Meng QC, Durand J, Oparil S, Elton TS: Enhanced endothelin-1 and endothelin receptor gene expression in chronic hypoxia. J Appl Physiol 1994;77:1451-1459.

67 Wang J, Weigand L, Lu W, Sylvester JT, Semenza GL, Shimoda LA: Hypoxia inducible factor 1 mediates hypoxia-induced TRPC expression and elevated intracellular $\mathrm{Ca} 2+$ in pulmonary arterial smooth muscle cells. Circ Res 2006;98:1528-1537.

68 Wang J, Chen Y, Lin C, Jia J, Tian L, Yang K, Zhao L, Lai N, Jiang Q, Sun Y, Zhong N, Ran P, Lu W: Effects of chronic exposure to cigarette smoke on canonical transient receptor potential expression in rat pulmonary arterial smooth muscle. Am J Physiol Cell Physiol 2014;306:C364-373.

69 Song MY, Makino A, Yuan JX: STIM2 Contributes to Enhanced Store-operated Ca Entry in Pulmonary Artery Smooth Muscle Cells from Patients with Idiopathic Pulmonary Arterial Hypertension. Pulm Circ 2011;1:84-94.

70 Yu Y, Fantozzi I, Remillard CV, Landsberg JW, Kunichika N, Platoshyn O, Tigno DD, Thistlethwaite PA, Rubin LJ, Yuan JX: Enhanced expression of transient receptor potential channels in idiopathic pulmonary arterial hypertension. Proc Natl Acad Sci U S A 2004;101:13861-13866.

71 Zhang S, Patel HH, Murray F, Remillard CV, Schach C, Thistlethwaite PA, Insel PA, Yuan JX: Pulmonary artery smooth muscle cells from normal subjects and IPAH patients show divergent cAMP-mediated effects on TRPC expression and capacitative Ca2+ entry. Am J Physiol Lung Cell Mol Physiol 2007;292:L1202-1210.

72 Fernandez RA, Sundivakkam P, Smith KA, Zeifman AS, Drennan AR, Yuan JX: Pathogenic role of storeoperated and receptor-operated $\mathrm{ca}(2+)$ channels in pulmonary arterial hypertension. J Signal Transduct 2012;2012:951497. 